LWSA

Local Wisdom, Social, and Arts

PAPER - OPEN ACCESS

Strategi Komunikasi Pariwisataberbasis Masyarakat Lokal (Studi Deskriptif Kualitatif Strategi Komunikasi Pariwisata oleh Masyarakat Karo Desa Rumah Galuh, Kecamatan Sei Bingai, Kabupaten Langkat)

$\begin{array}{ll}\text { Author } & : \text { Mazdalifah Mazdalifah } \\ \text { DOI } & : 10.32734 / \text { lwsa.v1i1.145 } \\ \text { Electronic ISSN } & : 2654-7058 \\ \text { Print ISSN } & : 2654-7066\end{array}$

Volume 1 Issue 1 - 2018 TALENTA Conference Series: Local Wisdom, Social and Arts

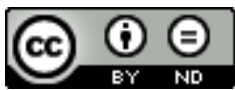

This work is licensed under a Creative Commons Attribution-NoDerivatives 4.0 International License.

Published under licence by TALENTA Publisher, Universitas Sumatera Utara
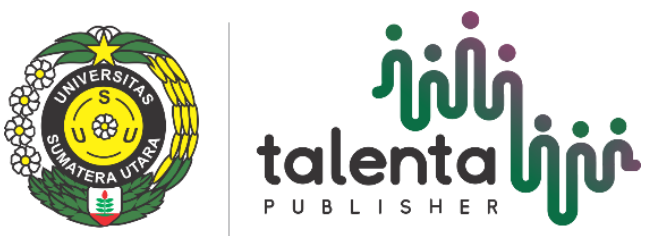


\title{
Strategi Komunikasi Pariwisataberbasis Masyarakat Lokal (Studi Deskriptif Kualitatif Strategi Komunikasi Pariwisata oleh Masyarakat Karo Desa Rumah Galuh, Kecamatan Sei Bingai, Kabupaten Langkat)
}

\author{
Mazdalifah $^{\mathrm{a}}$, Rusmi Charyani ${ }^{\mathrm{a}}$ \\ Fakultas Ilmu Sosial dan Ilmu Politik, Universitas Sumatera Utara, Medan-20155 \\ mazdalifah_jalil@yahoo.co.id
}

\begin{abstract}
Abstrak
Penelitian ini bertujuan mengetahui strategi komunikasi yang dilakukan masyarakat di Desa Rumah Galuh Kecamatan Sei Bingai Kabupaten Langkat dalam mengelola pariwisata berbasis masyarakat. Teori yang digunakan dalam penelitian ini adalah teori strategi komunikasi dan teori pariwisata berbasis masyarakat. Metode penelitian yang dipilih untuk menggali informasi di lapangan adalah metode wawancara mendalam dan observasi. Subjek penelitian adalah masyarakat yang menjadi pengelola wisata Desa Rumah Galuh yang berjumlah empat orang. Hasil penelitian menunjukkan bahwa dalam pengelolaan pariwisata masyarakat menggunakan strategi partisipatori, strategi media dan strategi mulut-ke-mulut.
\end{abstract}

Kata Kunci: Strategi Komunikasi; Pariwisata; Masyarakat

\section{Latar belakang}

Indonesia adalah sebuah negara yang memiliki keaneka-ragaman keindahan alam, budaya dan kesenian. Indonesia memiliki modal besar untuk menjadikan pariwisata sebagai salah satu pilar dalam menopang perekonomian negara. Sumatera Utara menempati posisi kelima pada tahun 2014 sebagai daerah dengan kunjungan terbanyak berdasarkan pintu masuk udara setelah Provinsi Bali, DKI Jakarta, Batam dan Kepulauan Riau. Badan Pusat Statistik (BPS) mencatat kunjungan wisatawan mancanegara melalui pintu masuk Bandara Kualanamu, Sumatera Utara mencapai 234.724 jiwa pada tahun 2014. Hal ini menunjukkan bahwa sektor kepariwisataan di Sumatera Utara turut berperan dalam meningkatkan perekonomian negara.

Desa Rumah Galuh mulai dikenal oleh wisatawan lokal pada sekitar akhir tahun 2013. Satu hal yang amat menarik adalah pengelolaan wisata ini dilakukan oleh masyarakat setempat. Pengelolaan pariwisata berbasis masyarakat lokal atau CBT (Community Based Tourism) telah mendapat perhatian dan perlu dikembangkan. Tiga prinsip pariwisata berbasis masyarakat yang perlu kita perhatikan yaitu pemberdayaan masyarakat, mengedepankan budaya dan mengedepankan lingkungan. Pariwisata berbasis masyarakat dapat didefinisikan sebagai sejenis parIwisata yang perkembangan dan pengelolaannya dikontrol oleh masyarakat setempat.

Mengupas strategi komunikasi oleh masyarakat etnis Karo di sekitar objek wisata Desa Rumah Galuh menjadi amat menarik karena dewasa ini pengelolaan pariwisata berbasis masyarakat lokal tengah mendapat sorotan penting. Hal lain yang menarik perhatian adalah keberadaan etnis Karo sebagai salah satu etnis batak yang ada di Sumatera Utara, yang selama ini digambarkan sebagai etnis yang gigih dalam bidang perdagangan. Di antara etnis Batak yang 
ada di Provinsi Sumatera Utara, etnis Karo bisa dikatakan sebagai etnis yang khas dengan tutur kata dan bahasanya yang mengalun lembut. Ciri khas berkomunikasi semacam ini mempunyai nilai positif bagi pengembangan parawisata di Desa Rumah Galuh.

\section{Kajian pustaka}

Pariwisata berbasis masyarakat merupakan suatu bentuk kepariwisataan yang mengedepankan kepemilikan dan peran serta aktif masyarakat, memberikan edukasi kepada masyarakat lokal maupun pengunjung, mengedepankan perlindungan kepada budaya dan lingkungan, serta memberikan manfaat secara ekonomi kepada masyarakat lokal. Tasci dkk menyebutkan bahwa pariwisata berbasis masyarakat lokal bukanlah sebagai sebuah konsep pengembangan pariwisata yang kaku. Asker (dalam Anom Hery Suasapha, 2015: 10) mengemukakan tiga prinsip pariwisata berbasis masyarakat yaitu pemberdayaan masyarakat, mengedepankan budaya dan mengedepankan lingkungan. Selanjutnya Hausler and Strasdas menyatakan bahwa pariwisata berbasis masyarakat merupakan sejenis kepariwisataan yang perkembangan dan pengelolaannya dikontrol oleh masyarakat lokal, dimana bagian terbesar dari manfaat yang dihasilkan kepariwisataan tersebut dinikmati oleh masyarakat lokal, baik yang terlibat secara langsung maupun tidak langsung dalam kepariwisataan tersebut, serta memberikan pendidikan bagi pengunjung maupun masyarakat lokal mengenai pentingnya usaha konservasi terhadap alam dan budaya. Definisi Community Based Tourism atau pariwisata berbasis masyarakat adalah; (a) bentuk pariwisata yang memberikan kesempatan kepada masyarakat lokal untuk mengontrol dan terlibat dalam manajemen dan pembangunan pariwisata; (b) masyarakat yang tidak terlibat langsung dalam usaha-usaha pariwisata juga mendapat keuntungan; (c) menuntut pemberdayaan secara politis dan demokratisasi dan distribusi; (d) keuntungan kepada komunitas yang kurang beruntung di pedesaan ( Cahya : 2012 ).

Strategi komunikasi menjadi penting dalam menerapkan pariwisata berbasis masyarakat. Sebagai pelaku utama pengelolaan objek wisata potensial, masyarakat perlu memahami dengan baik sumber daya dan karakter yang mereka miliki. Suatu strategi merupakan keseluruhan keputusan kondisional tentang tindakan yang akan dijalankan guna mencapai tujuan. Jadi dalam merumuskan strategi komunikasi, selain diperlukan perumusan tujuan yang jelas, juga terutama memperhitungkan kondisi dan situasi khalayak. Masyarakat Karo pada umumnya masih memegang teguh nilai dan norma-norma dari sangkep nggeluh. Pada masa sekarang ini hubungan kekerabatan masyarakat Karo masih tetap merupakan suatu unsur yang penting dalam segala aspek kehidupan. Jaman Tarigan mengatakan hubungan kekerabatan pada masyarakat Karo berdasarkan merga. Ideologi-ideologi merga telah mempersatukan masyarakat Karo ke dalam sistem kekerabatan sangkep nggeluh meskipun mereka tidak memiliki keterikatan genelogis yang dapat ditelusuri. Namun, ada dua hal penting yang mempengaruhi hubungan sangkep nggeluh, yaitu kelahiran dan perkawinan. Kedua hal tersebut akan menimbulkan hubungan genetika yang dapat diketahui jauh dekatnya hubungan kekerabatan dalam masyarakat Karo itu sendiri

\section{Metode Penelitian}

Data yang digunakan dalam penelitian ini dikumpulkan melalui metode wawancara mendalam dan observasi. Wawancara dilakukan dengan beberapa pengelola wisata berbasis masyarakat di desa Pelaruga terkait strategi komunikasi yang digunakan masyarakat etnis Karo di Desa Rumah Galuh dalam melakukan komunikasi parawisata. Pengamatan dilakukan untuk melihat bagaimana masyarakat setempat mengelola pariwisata berbasis masyarakat.

\section{Hasil dan Diskusi}

Masyarakat Desa Rumah Galuh mulai mengembangkan sumber daya alam berupa aliran mata air yang terdapat di desa tersebut menjadi satu objek wisata hingga mampu menjadi Daerah Tujuan Wisata yang ada di Kabupaten Langkat. Segala bentuk peranan dalam usaha mengembangkan objek wisata tersebut dikelola sepenuhnya oleh masyarakat setempat. Pelaruga adalah nama komunitas yang dibentuk oleh masyarakat untuk mengembangkan objek 
wisata Desa Rumah Galuh. Alasan mengapa komunitas ini dibentuk secara sederhana untuk menyediakan lapangan pekerjaan bagi pemuda setempat.

Mekanisme pengelolaan wisata Desa Rumah Galuh oleh komunitas Pelaruga menunjukkan bahwa ada struktur pengurus yang baku. Struktur ini terdiri dari masyarakat lokal yaitu pemuda etnis Karo yang mengusung semangat kebersamaan diantara mereka. Hal ini sesuai dengan strategi partisipatori dalam pembangunan dimana dalam setiap aktivitas pembangunan hendaknya melibatkan masyarakat dalam setiap kegiatan pembangunan. Individu-individu mendapat tugas dan tanggung jawab berdasarkan adanya ikatan kekeluargaan. Hal ini senada dengan sifat dan ciri khas masyarakat etnis Karo yang menjunjung tinggi rasa kekeluargaan yaitu menjunjung tinggi nama baik keluarga dan harga diri. Hal-hal yang berkaitan dengan pengelolaan kerja lebih terasa nyaman jika dibagi bersama keluarga, sebagai orang yang dipercayai. Keluarga menurut mereka adalah orang terdekat, yang apabila terjadi kesalahan akan lebih mudah untuk menasihatinya.

Selain strategi partisipatori kegiatan parawisata Desa Rumah Galuh menerapkan pula strategi media, dimana dalam kegiatan ini memanfaatkan media dalam menyebarluaskan pesan kepada masyarakat. Hasil penelusuran memperlihatkan bahwasanya informasi tentang wisata Desa Rumah Galuh banyak diketahui melalui media sosial. Anggota komunitas Pelaruga menciptakan kenyamanan pengunjung dengan mengakrabkan diri dengan para wisatawan sehingga dapat menumbuhkan rasa ingin kembali berkunjung. Strategi ini bertujuan agar pengunjung dapat mengajak teman-teman yang lain untuk datang ke Desa Rumah Galuh, tepatnya ke komunitas Pelaruga. Keakraban yang terbina diharapkan akan meninggalkan kesan tersendiri, dimana diharapkan nantinya pengunjung akan bercerita bahwa Desa Rumah Galuh adalah tujuan wisata yang mendapat rekomendasi untuk dikunjungi. Proses bercerita dari mulut ke mulut atau yang dikenal dengan komunikasi dari mulut ke mulut diharapkan dapat menciptakan efek Bola Salju yang kian lama kian membesar dan terus mengelinding menjadi lebih besar lagi.Selain strategi partisipatori kegiatan parawisata Desa Rumah Galuh menerapkan pula strategi media, dimana dalam kegiatan ini memanfaatkan media dalam menyebarluaskan pesan kepada masyarakat. Hasil penelusuran memperlihatkan bahwasanya informasi tentang wisata Desa Rumah Galuh banyak diketahui melalui media sosial. Anggota komunitas Pelaruga menciptakan kenyamanan pengunjung dengan mengakrabkan diri dengan para wisatawan sehingga dapat menumbuhkan rasa ingin kembali berkunjung. Strategi ini bertujuan agar pengunjung dapat mengajak teman-teman yang lain untuk datang ke Desa Rumah Galuh, tepatnya ke komunitas Pelaruga. Keakraban yang terbina diharapkan akan meninggalkan kesan tersendiri, dimana diharapkan nantinya pengunjung akan bercerita bahwa Desa Rumah Galuh adalah tujuan wisata yang mendapat rekomendasi untuk dikunjungi. Proses bercerita dari mulut ke mulut atau yang dikenal dengan komunikasi dari mulut ke mulut diharapkan dapat menciptakan efek Bola Salju yang kian lama kian membesar dan terus mengelinding menjadi lebih besar lagi.

Strategi yang dilakukan komunitas Pelaruga baik dengan strategi Bola Salju maupun dari mulut ke mulut adalah dua cara yang tidak terlepas satu sama lain. Komunitas Pelaruga memanfaatkan hubungan simbiosis mutualisme yang terjadi dengan komunitas travelling. Komunitas travelling akan menjelajahi tempat-tempat wisata, yang nantinya dapat dijadikan rekomendasi bagi para wisatawan. Sampai pada saat ini, tata cara pengelolaan pariwisata Desa Rumah Galuh terus dibenahi, begitu pula dengan kegiatan strategi komunikasi dalam memperkenalkan dan mengembangkan wisatanya. Masyarakat lokal yang notabene masyarakat etnis Karo bersikap terbuka dalam menerima saran yang diberikan pengunjung yang bersifat positif. Beberapa sifat dasar khas sebagai masyarakat etnis Karo turut memperkaya strategi komunikasi pariwisata Desa Rumah Galuh.

\section{Kesimpulan}

Strategi komunikasi dalam mengelola wisata Desa Rumah Galuh adalah menggunakan strategi partisipatori yaitu strategi yang melibatkan masyarakat setempat sebagai pelaku aktif dalam mengelola wisatanya. Selanjutnya menggunakan strategi media, dimana pihak pengelola memanfaatkan media sosial dalam menyebarluaskan informasi wisata Rumah Galuh. Penyebarluasan informasi wisata Desa Rumah Galuh menggunakan strategi Bola Salju dan komunikasi dari mulut ke mulut. Dimana dalam hal ini pengelola yang umumnya beretnis Karo amat berperan sebagai ujung tombaknya. Sifat dan ciri khas sebagai etnis Karo menjadi penyumbang terhadap kesuksesan strategi ini. 
Inisiatif yang dilakukan oleh masyarakat Desa Rumah Galuh dalam mengembangkan potensi alam yang ada sebagai sebuah ekowisata seharusnya menjadi sebuah keuntungan bagi pihak pemerintah. Pendidikan pariwisata sebaiknya diberikan kepada masyarakat, agar muncul kesadaran kepemilikan bersama terhadap objek wisata untuk dikembangkan secara bersama-sama. Seluruh stakeholder wisata Desa Rumah Galuh, masyarakat, pemerintah, pengelola dan pengunjung, bersama-sama berpartisipasi dan menerapkan strategi komunikasi yang lebih baik, dalam rangka meningkatkan kunjungan wisata dan meningkatkan taraf hidup masyarakat. .

\section{Daftar pustaka}

[1] Bangun, T. (2006). Sifat dan Tabiat Orang Karo. Jakarta: Yayasan Lau Simalem.

[2] Bungin, B.(2009). Metode Penelitian Kuantitatif, Komunikasi, Ekonomi, dan kebijakan Publik serta Ilmu-ilmu sosisal lainnya, Jakarta: Kencana.

[3] Cahya P. (2012). Strategi Pemasaran Produk Wisata Minat. Khusus Goa Cerme Imogiri. Tesis tidak dipublikasikan. Universitas Gadjah Mada. Yogyakarta.

[4] Effendi, O. U. (2000). Ilmu Teori \& Filsafat Komunikasi. Bandung: Citra Aditya Bakti.

[5] Ginting, G. (2015). Perkawinan Semerga (Studi Etnografi Merga Silima Masyarakat Karo di Desa Sugau, Kecamatan Pancur Batu, Kabupaten Deli Serdang. Unpublished undergraduate's thesis. University of Sumatera Utara. Medan.

[6] Ginting, P. (2008). Filsafat Ilmu dan Metode Riset. Medan: USU Press.

[7] Harun, R. and Elvinaro, A. (2012). Komunikasi Pembangunan dan Perubahan Sosial: Perspektif Dominan, Kaji Ulang, dan Teori Kritis. Jakarta: Raja Grafindo Persada.

[8] Misdasy, T. (2012). Negri Suah (Studi Etnografi Objek Wisata di Desa Negeri Gugung, Kecamatan Sibolangit, Kabupaten Deli Serdang. Unpublished undergraduate's thesis University of Sumatera Utara. Medan.

[9] Moleong, L. J. (2005). Metodologi Peneitian Kualitatif edisi revisi. Bandung: Remaja Rosdakarya.

[10] Rakhmat, J. (2004). Metode Penelitian Komunikasi. Bandung: Remaja Rosdakarya.

[11] Suasapha, A, H. (2015), Implementasi Konsep Pariwisata Berbasis Masyarakat Dalam Pengelolaan Pantai Kedonganan Sebagai Daya Tarik Wisata. Unpublished master's thesis. University of Udayana. Denpasar.

[12] Sugiyono. (2008). Metode Penelitian Kuantitatif Kualitatif dan R\&D. Bandung: Alfabeta.

[13] Sutopo. (2006). Penelitian Kualitatif: Dasar Teori dan Terapannya Dalam Penelitian. Surakarta: Universitas Sebelas Maret 